\title{
Geo-economics vs Geo-politics: The Baghdad Railway Project and the Spoils of a Perpetual Economic War around Middle East
}

\author{
John Karkazis \\ Dean of Business School, \\ University of the Aegean, Chios, Greece \\ loannis G. Vidakis \\ Ph.D. of Business School, \\ University of the Aegean, Chios, Greece \\ Georgios C. Baltos \\ Ph.D.(c) of Business School, \\ University of the Aegean, Chios, Greece \\ Joseph N. Bayeh \\ Chairperson of $U O B$, \\ Department on Political Science and International Affairs, \\ Balamand University, Beirut, Lebanon
}

Doi: 10.2478/ajis-2019-0032

\section{Abstract}

This study focuses on the geopolitical situation in the wider East Mediterranean Region at the dawn of the $20^{\text {th }}$ century, based on the analysis of a major infrastructure project, the Baghdad Railway. The process of its construction eventually led to the rivalry between "Politics" and "Economy", towards increased relative gains for the superpowers of that period. The innovative side of the research extends to the hypothesis that modern economic crises are also related to power games similar to those prevailing almost a century ago. International Relations are linked with the Politics and Economy sectors, considering realistic lessons from the past in order to shape another better in terms of peace and stability future.

Keywords: Geopolitics, Geo-economics, Geo-energeia, Baghdad Railway, Middle East, Energy Resources, Economic Crises

\section{Introduction}

"The Merchants of Nations", a popular Alexandros Papadiamantis' novel, refers to the $12^{\text {th }}$ century, when Venetians and Genoese, merchants and pirates, raided and occupied the Cyclades islands, driven by self-interests, although their campaign started under the 4th Crusade scheme. Marco Sanudo, a nephew of Enrico Dandolo, campaigned against the Byzantine Aegean Archipelago. The power of Venice was being spread, the Aegean islands were unable to resist, reminding that power usually perpetuates only in an expansionary manner. The powerful Venetians had a strong belief that those who do not exercise offensive realist politics inevitably weaken since it is a matter of time 
for them to lose control as long as without expansionism they would have never managed to accumulate power and prove their superiority (Papadiamantis, 2011).

The lines above refer briefly to the territory of the Eastern Mediterranean and the Middle East in 1199, while the following geo-historical analysis attempts to present, through the examination of the Baghdad railway project, the confrontation among specific aspects of economy, politics and international relations, but also the posterior effort of rewriting the history by shadowing the original sources.

\section{The Research Scope and Methodology}

\subsection{Geo-Politics versus Geo-Economy}

Over the last decades, major changes have taken place in the Eastern Mediterranean and the Middle East, raising questions concerning the causes along with the decision-making patterns in the area. Answers can, however, be received through an in-depth examination of the value sourcing out of the field of natural resources and especially of energy resources in the region. The Great War in the early 20th century, as mainly a European pandemic disease, destroyed at least a couple of generations, when it inevitably caused the Second World War. The Allies argued that only Germany was responsible for the conflict and, therefore, responsible for all the cost and the losses suffered by the winners of the war. In the general geo-historical framework of the events that took place in the broader Near East, we consider that in order to research for the motives of past events, to understand and interpret the current situation and the present "order of things" as well as the forthcoming developments, it is required to follow an interdisciplinary research, so that we do not neglect the important role of the Great Powers during each era and the emergence of the "oil factor" as an important element of choice and of the decision making processes (Vidakis, Baltos, \& Balodis 2017). In critical times, like those we live today, the historical memory is always present and of great importance.

Aiming at a synthetic approach, we examined the primary research work of Professor Edward Mead Earle, University of Columbia, USA, (1923), titled: "Turkey, the Great Powers and the Baghdad Railway: A Study on Imperialism". This study examined the important factor of the "Baghdad Railway", which it is argued to connect the academic fields of Geo-Economy, Geopolitics, International Relations and the energy sector, known at that time as the coal and oil industry. The author associates, presenting the corresponding evidence, the interests of the Great Powers in a close relation to the imperialism and the outbreak of the Great World War.

The Baghdad Railway was similarly perceived and launched not only as a project of great hope for the economic and political revitalization of the Near East, but also a source and means of international rivalry, thus contributing to the eruption of the Great War. It is one of the tragedies of the 19th and 20th centuries that the Canal of Suez, the Trans-Siberian and the Baghdad railroads apparently powerful tools of the civilized world in order to promote peaceful progress and material prosperity - could not have been built without provoking imperialist frictions, political intrigues, military alliances and armed conflicts. In particular, if someone aims to understand the diplomatic history of the War, "he only needs to study the struggle for the Baghdad Railway - he will find there a workshop full of useful tools" (Earle, 1923, p.3,4).

\subsection{Literature Review}

All the political, economic and technical aspects of such an ambitious and industrious project have been reflected in the rich bibliography interpreting the relevant facts in multi-faceted ways. A first group of sources may be identified with reference to their chronological order, i.e. a series of contemporary scholars capture the strategies and policies that preceded or resulted in a world war. In 1915, Hogarth was reviewing the Germans' railroad plans as the successor to numerous, previous but vain, British efforts to build railways toward the Euphrates valley (Hogarth, 1915). A few years ago, Fraser was considering the project in discussion as a journey or a "short cut" to India, suggesting, in accordance with Geraud's recommendations (Geraud, 1914), that Great 
Britain should take the lead, if not the exclusive control, in the railway operations to the East (Fraser, 1909). Pears, at the same time, was supporting the Balfour proposal for internationalization of the Middle Eastern railway lines as a pre-requisite of peace in the region (Pears, 1908).

The famous then journalist Edward Dicey highlighted the advantages of an Anglo-German cooperation (Dicey, 1866, 1903), while Gwinner emphasized on the economic impact of the Baghdad railway on the Ottoman economy (Gwinner, 1909). Lynch, on the other side, was warning over the increased German influence in the area (Lynch, 1911). Woods illustrated the whole research and analyses with plenty of maps and geographical material (Woods, 1917), while Schreiner drew the attention to the background scene of multi-national antagonisms (Schreiner, 1918). The contribution of German strategists and scholars, like Max Wiedemann, Paul Rohrbach and Ernst Jackh completes the historical overview along with the multi-level analysis of the "Drang nach Osten" contemporary developments (Jäckh, 1915; Rohrbach, 1915; Wiedemann, 1911).

Beyond the popular analysis of Earle pointing out the role of imperialism in decision making (Earle, 1923), in the aftermath of the world wars turmoil, Maloney revises the progress of the project from its first to the last day (Maloney, 1984), while Benns concludes in recognizing the Baghdad railway a symbol, if not a cause, of the $1^{\text {st }}$ World War itself (Benns, 1941). A decade later, in the 60's, Ravinder Kumar (Kumar, 1962), Ulrich Trumpener (Trumpener, 2015), Jacob M. Landau (Landau, 2016) and Yaqub N. Karkar (Karkar, 1972), whose works have been lately republished, introduce alternative perspectives, considering several historiographical accounts from Indian to the Ottoman archives. Over the last two decades, plethora of publications add depth and value to the older accounts of the construction project in discussion. Stating its pivotal role in the international relations at the dawn of the $20^{\text {th }}$ century, Jonathan S. McMurray examines the ties between Germany and Turkey (McMurray, 2001). Mustafa Sıtkı Bilgin performs exhaustive review of the Anglo-Turkish relations (Bilgin, 2004). Peter Hertner discusses the phenomenon of foreign investments in favor of building Balkan railways. Katie Ayrton Somerwil dramatizes the feature of "a train that disappeared" on the way from Berlin to Baghdad (Somerwil-Ayrton, 2007). Niles Stefan Illich focuses on the German imperialism over the first half of the $20^{\text {th }}$ century (Illich, 2007). Sean McMeekin interprets the Berlin-Baghdad Express as the first Germany's bid for world power (McMeekin, 2012). Metin M. Hülagü recalls the advantages of another railway line, namely the "Hejaz", which was eventually accomplished (Hülagü, 2010). William D. Middleton places the Baghdad Railway in the context of a legendary railways history (Middleton, 2011). Last but not least, Valerie $\mathrm{H}$. Atwood reviews the project in correlation with the demise of Ottoman Empire in the terms of the so-called Eastern Question (Atwood, 2013).

\subsection{Planning and Contracting the Baghdad Railway}

As it was mentioned before with regard to the Baghdad Railway, researchers lately paid much more attention to its role rather than in the late 19th and early 20th century. Railways would already connect Berlin and other major European cities with the Istanbul-Baghdad line, via the lands of the decadent at those times Ottoman Empire. Istanbul had already been linked by train with Paris and London, since 1888, putting into operation the famous "Orient Express". In the same year, a German consortium named "Anatolian Railway Company" (ARC) was initially authorized by the Ottomans for the construction of a railway in Asia Minor. In 1893 the Haidar Passa - Nicomedia Ankara line was delivered. In the same year, ARC was commissioned to construct a railway line, $444 \mathrm{~km}$ long, from Eski Shehir (or Doryleon, a town in the middle between Nicomedia and Ankara) to Konia, which was completed in 1896. In 1899 the Sultan granted ARC the construction of a railway network from Konia to Baghdad and the Persian Gulf. The relevant contract was finalized in 1903 with the establishment of Baghdad Railway Company (BRC) in cooperation with ARC.

Already since 1901, German decision makers had reported the existence of huge oil fields in the areas of Tigris and Euphrates. However, around this third assignment many economic, natural, technical, political and diplomatic barriers had been appeared. After the final concession, mainly Great Britain and, secondly, France and, to a lesser extent, Russia, considered that the completion of this network could probably put in risk the interests, the power balance and the relative positions of the stakeholders in the global power distribution (Vidakis, 2016). 
Among these three Great Powers, London initially supported the German plans (considering that they were too ambitious to be implemented and also believing that due to expansion, Berlin would be in a difficult position - competitive imperialism), Paris agreed on having a minority stake in BRC (profit sharing - cooperative imperialism) and finally Moscow, having succeeded in changing the initial route design of the railway, had been inactive (non-competitive imperialism).

During the period 1870-1890, the French and British influences on the Sublime Porte gradually declined. In 1897, Von Wangenheim was replaced by Marschall von Bieberstein as ambassador to Istanbul. The later was a former Foreign Ministry official, a prominent German bureaucrat who supported a strong political and economic alliance between the German and Ottoman Empires. The conflicting interests were now extended to many fields, thus becoming systematic. Especially in 1899, due mainly to the Russian objections to the construction of railways in northern Asia Minor, the construction of the project was focused on a southern line, from Konia (Ikonion) to Baghdad through Aleppo and Mosul (see Map 1 below).

After a short period of intense competition for the concession in 1899, Deutsche Bank group's possession rights remained intact, the Russians had finally withdrawn due to lack of support from Moscow, the French investors had received a stake in the German company and the British proposals had lost their support when the difficulty of the Boers war in South Africa temporarily overshadowed all other open issues. Therefore, the assignment of the Baghdad railway system had to be to the German ARC. This company had already recorded a very successful course when it comes to its relations with the Ottoman Ministry of Public Works. The existing lines worked well for the Ottoman Government, the Anatolian farmers and business persons. The difficulties that the concessionaries were facing were not political but mainly financial and administrative.

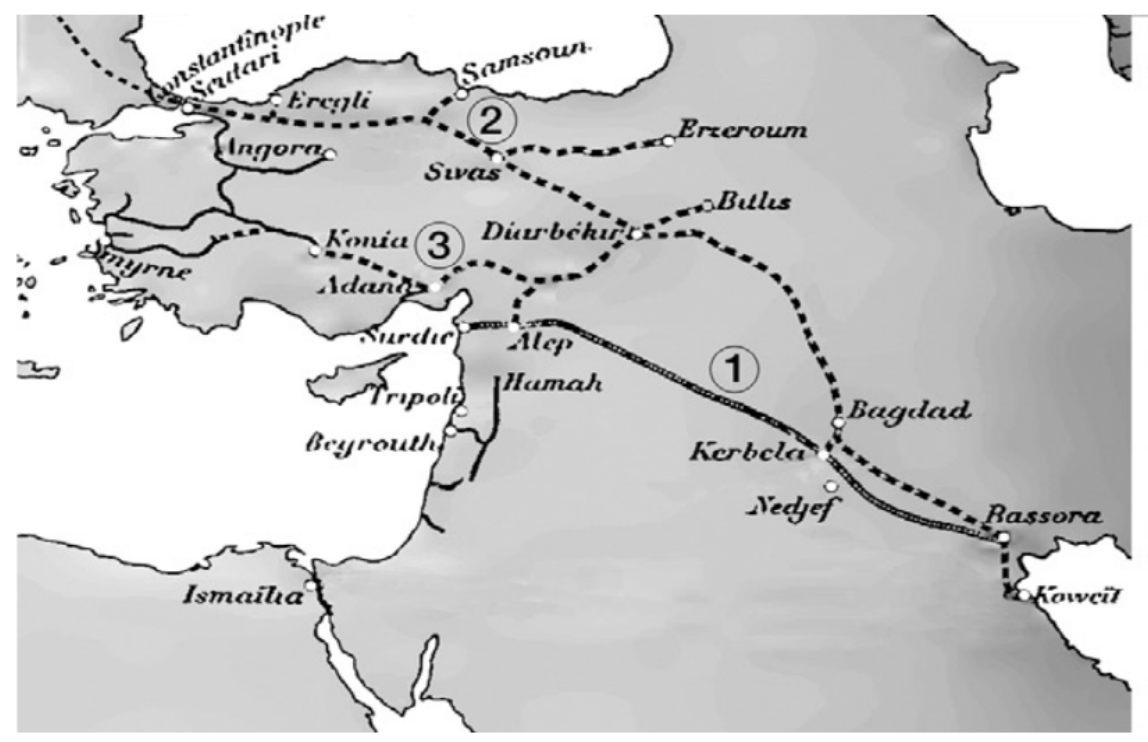

Map 1: Railway Network Plans in Asia Minor (Pallini \& Scaccabarozzi, 2011)

In 1902, an economic recession occurred and, especially in Germany, the financial conditions were clearly not in favor of the bond-related funding of the project. Therefore, Deutsche Bank signed with the new company, called the Baghdad Railway Company (BRC), a revised contract for the Baghdad Railway on the $5^{\text {th }}$ of March 1903. It had become obvious that the Ottomans were expecting important gains on behalf of the German concessionaires and their French counterparts. The new 99-year contract, starting from 1903, provided for the construction of a "Central Line" from Konia, the southeast end of the existing railways, down to the Persian Gulf. The concessionaires were obliged to complete the whole project until 1911. 


\section{Results}

\subsection{The "oil-maniac" geo-energy initiatives: The Great Britain's reaction}

However, at that time, Great Britain appears to be more dynamic, compared to the past, in asserting its interests; Admiral John Fisher, the so-called "oil-maniac" (Jones, 1981, p. 14), takes on the Royal Navy's title of "Second Sea Lord» (Commander of Education and Supply chain) and introduces broad reforms during the period 1902-1904. In July 1902, Arthur Balfour succeeded his uncle as prime minister and focused on improvements in defense policy, supporting Fisher's innovations. He focuses on the formation of an "Entente Cordiale" with France (April 1904). In 1904, Fisher took over as Chief of the Royal Navy, driving in 1906 to the construction of the technologically upgraded «HMS Dreadnought», in order to maintain British maritime power projection against the German threat of building the most powerful fleet. That same year, British Prof. Halford John Mackinder publishes his geopolitical theory of "Heartland", the approach for a Worldwide Island, namely Eurasia and Africa, and the notion of "The Heart of the Earth". A little earlier, the American Alfred Thayer Mahan had already presented and supported the superiority of sea powers (Vidakis, 2016).

The introduction of huge diesel fuel needs in combination with the lack of crude oil in the UK's territory highlighted as the highest priority of national security the storage of large oil reserves outside the UK. In November 1904, the Fuel Oil Committee was established and decided along with the British Ministry of Colonies the prohibition of a majority shareholding in any consortium for exploration and exploitation by non-British. In addition, the British Ministry of Colonies decided to ensure that the most promising oil company in the region of today's south-western Iran would remain under British control, despite the fact that it was outside the empire's administrative boundaries (Alobeid, Vidakis, Baltos \& Balodis, 2018). We should not neglect to mention that the "energy explosion" had begun in the late 19th century and was closely connected with the massive use of oil (Vidakis \& Baltos 2015).

However, domestic political developments in Great Britain set serious obstacles in the completion of the project for the oil-powered fleet and the oil-powered super-battleships. The result of the December's 1905 elections was a liberal government with a neutral strategy against Germany, especially after the Moroccan crisis (1904-1905), and a program to reduce arms in order to save resources for financing social policies. As a result, the Raw Materials Committee was abolished and the Petroleum Fuel Committee, which had recognized the importance of oil as a strategic raw material was dissolved in 1906 (Jones, 1981). Nevertheless, the British assured the control of southwestern Persia, as a result of the Persian Revolution (1906) and the Russian-British (Entente) alliance (St. Petersburg Treaty, August 1907). Asquith government's economists after 1908 made every possible effort to cancel Fisher's extensive and costly naval program. As Yergin (2009) pointed out Churchill and Lloyd George even supported an Anglo-German naval agreement as a means to restrict naval budget and save resources for strengthening social reforms.

The decisive turning point for the emergence of oil as of strategic importance for supplying the British fleet can be spotted in the geostrategic causes of the second Moroccan crisis of Agadir, during the summer of 1911, i.e. Germany's power demonstration through the mission of battleship "Panther» to the port of Morocco, succeeded in unifying the whole anti-German coalition in London, highlighting the magnitude of the challenge and the possible threat to the British overseas domination (Yergin, 2009). In the autumn of 1911, Winston Churchill, one of the leaders among the liberal economists, was appointed senior political chief of the Admiralty and fully adhered to the strategy of retired Admiral Fisher. With the help of Churchill, the Admiralty finally succeeded in realizing its plans, comprised by the use of oil on warships and the follow-up order of five oilpowered ships. The British government was anxiously trying to secure oil resources by supporting British companies like the Burmah Oil Company, the Royal Dutch Shell group (founded in February 1907 ) and the investment of William Knox D Arcy's in southwestern Persia, due to the discovery of crude oil in 1908 and the formation of the Anglo-Persian Oil Company, APOC (Rogan, 2016).

Churchill, in July 1912, managed to establish the first official state committee of "Energy Security" in the history, under the leadership of Fisher. The Royal Oil Commission (Royal 
Commission on Oil and the Oil Engine) supported the project of a diesel-powered fleet and successively decided (Vidakis, 2016):

a. the largest armament program in the history of British Navy (1912-1914), that led to the construction of six diesel-powered ships,

b. the development of the first strategic oil reserve for the fleet,

c. the immediate acquisition by the British state of the $51 \%$ of the "Anglo-Persian" company in 1914, which was the first state direct investment outside the British Empire.

Consequently and in the context of the "geo-energeia" or so-called geo-energy approach (I. Vidakis \& Baltos, 2015), the introduction of the factor of Mesopotamian's oil, the proximity of the Baghdad railway terminal to the Persian oil fields, Great Britain's need for fuel, that was a sine qua non condition for its technologically advanced and modernized fleet ("dreadnought-type"), and the fast-growing world oil economy, changed its strategic attitude. When, in 1911, the BRC proposed a junction from Alexandretta to Aleppo, which would serve the trade needs with northern Syria and northern Mesopotamian Valley, Great Britain rejected the proposed increase of trade tariffs from the Ottoman Empire, as a means of financing the above-mentioned plan; entrepreneurship had to retreat in favor of geopolitical necessities.

\section{Discussion}

\subsection{The Ottoman political changes re-engineer the project}

It should be noted that London's strategy was aiming to secure the British domination over the Middle East and the existing oil reserves. Great Britain acted effectively and on time, before the entry of the Ottoman Empire in the conflict concerning the occupation of Basra (Fromkin, 1989). Then, in April 1915, Great Britain attempted to take control of the empire by striving directly against Constantinople, preventing the Russians landing on the Gallipoli Peninsula. The campaign ended in the withdrawal of the above-mentioned forces at the end of the year. However, the United Kingdom continued its effort by signing and entering the Sykes-Picot secret agreement. It was agreed on 16 May 1916 between the UK and France, with the agreement of Tsarist Russia, and defined the zones of influence and control in the area of wider Middle East, after the expected collapse of the Ottoman Empire.

When, after the Russian Revolution of 1917, the Bolsheviks denounced secret diplomacy and published, among others, the secret Sykes-Picot's agreement, the Arabs became aware of the backstage diplomacy and negotiations proceedings, while according to the Balfour Statement addressed to Lord Rothschild, leader of the British Jewish Community, British Foreign Ministry announced its support for the creation of a national home for the Jewish people in Palestine. At the same time, the British had put at the center of their geopolitics, as the most valuable objective, the oil reserves of Mosul, taking into account the fact that they were no longer in risk of bordering the Russians (Yergin, 2009).

For Great Britain, due to the absence of domestic oil resources, the greatest possible diversification of alternative sources of import was the most important means of satisfying the energy needs of its military fleet, in a first attempt to define and implement an Energy Security plan. The First World War soon began, at the end of which the Foreign Minister Curzon said that the Allies had come to victory by floating in ocean waves (Yergin, 2009). Consequently, the First World War confirmed that oil was one of the main causes of dominance in the battlefield (Vidakis, Baltos, \& Balodis, 2017).

In summary, Baghdad's railway project was increasingly seen in London as a threat to the future security of crude oil logistics. Great Britain supported the interests of all UK companies. From oil and for oil, an intense struggle for dominance of a large-scale trusts coalition launched, representing the interests of the involved entrepreneurs, accompanied by the respective and intervening governments (Vidakis, 2016). One month later (July 1908) the New-Turks revolted, while England appeared to take place against the tyrannical Sultan and not against the Ottomans, expecting to create a breach in the German-Turkish relations.

On the $2^{\text {nd }}$ of September 1908 the first general strike in the history of Ottoman railways broke 
out. In the autumn of 1908 the first Parliament was put into operation giving to the opponents of the Baghdad Railway the following opportunity; Ismail Hakki Bey declared the project as a political and economic monstrosity, which could be executed only under an authoritarian and corrupted government, thus proposing the complete denial of contracts with Deutsche Bank. In October, Bulgaria declared itself as an independent kingdom, the Cretans declared the union with Greece and Austria annexed Bosnia and Herzegovina. In the same year, BRC's German investors tried to establish cooperation with British capital owners.

Then, a coup against the Neo-Turks (April 1909) takes place accompanied by atrocities against Armenians in Adana and elsewhere, but, ultimately, the Neo-Turks prevail and, as a result, Kaiser's faithful friend, Abdul Hamid is dethroned. The following month, Dwinner, as representative of Deutsche Bank, is visiting London trying to achieve the British cooperation. Serving their own interests, the Neo-Turks tried to exploit the Great Powers' competition, but eventually they succeeded in creating coalitions which aimed either at the dissolution and the distribution of its territories or at the exploitation of the Ottoman Empire.

In the summer of 1910, Djavid Bey, the Ottoman Finance Minister, goes to Paris and London for a $\$ 30$ million loan, which was finally granted by Germany. In March 1911, the Ottomans submit a proposal to the British-French for the internationalization of BR (Baghdad-Basra section) construction by an Ottoman company, in the capital of which the Turkish government would share $40 \%$, while German, French and British capitalists would keep the rest. At the end of September 1911, the Italians invaded Libya (declaration of Italian-Turkish war) and in May 1912, they occupy the Dodecanese. In October, the First Balkan War broke out, while in February 1913, Hakki Pasha, an Ottoman envoy, arrived in London to settle the existing differences with Great Britain. For nearly four months, Hakki Pasha and Sir Edward Gray discussed the issues concerning the Near East and spoke with Von Kuhlmann and Prince Lichnowsky, on behalf of the German Embassy in London, on the terms of a trilateral arrangement of the important economic and political issues. Finally, the failure of a satisfied settlement for the distribution of the profits will inevitably lead in 1914 to the break out of the Great War, with the main objective being the lands and wealth of the Near East.

\subsection{A push toward the Middle Eastern geo-energy ("Drang nach Osten")}

Beyond Bosporus, there was a country potentially rich in oil and metals, a country that in ancient times was extremely rich in agricultural products and promised to develop into a rich market for the western products. The transportation across this area should be conducted by a German-controlled railway, which in turn could be kept in service in times of war, as well as in peacetime, without the help of naval forces. Turkey intended to be included in the economic trajectory of an industrial Germany. The latter, encircled by Britain, France and Russia, was slowly preparing to expand its dominance over the peripheral and colonial sectors, given it was unable, only because of lack of coal power plants, to develop its own sea power greater than that of its opponents.

The main consequence of these facts was the German perception of a "push towards the east" (Drang nach Osten) through the Balkan Peninsula to the Istanbul Bridge and the markets of Asia. The geographical location of the Central European States had made inevitable a policy of penetrating Balkans, Asia Minor and Near East, as the geographic position of England had made it inevitable to develop an overseas empire. If Germany had remained inactive concerning the acquisition of a stake in Mesopotamia, Syria and Babylonia, other forces of the international system would have taken the initiative instead.

In fact, this dominance over the Balkan regions to the southern Mesopotamia was a wide route of communication, a worldwide historic avenue between the West and the East. For a powerful nation, this position would be a power multiplier. However, for a weak nation or an empire on demise, like the Ottoman one, it would probably turn into an additional source of weakness. Similar to the positions of Gibraltar, Suez and Panama, there were Istanbul, Smyrna and Kuwait (Athanasopoulos \& Karkazis, 1997). Strategically, the area that the Baghdad railway was planned to cross is one of the most important parts of the world. Furthermore, the Empire had still potential over its Asian territories. It possessed huge resources of basic materials for the industry, while alone the deposits of crude oil were enough to stimulate the greed of the Great Powers. Watering 
was believed that would carry out miracles leading to the revival of the ancient fertility of Mesopotamia. With the development of the latent agricultural wealth of the country and the use of its industrial capabilities, the Ottoman Empire was expected to be a valuable source of raw materials of vital importance, a satisfactory market of final goods and a rich field for capital investment. In economic terms, the territory that would be served by the Baghdad railway was one of the most underdeveloped places in the world, promising though potential prospective (Stellakou \& Karkazis 1992).

Earle (1923) claimed that Turkey's economic outlooks were never brighter than they were during the period before the outbreak of war, but he also noted that:

a. the economy was under the control of the Ottoman Administration of Public Debt, which controlled the Ottoman economic policy and exercised its control in the interest of European bankers and investors;

b. the Great Powers "pretended" but they did not pursue tolerance against the sovereignty and territorial integrity of the Ottoman Empire;

c. the Baghdad Railway and the international complications that have emerged from it, lead to the destruction of the Ottoman Empire.

It is a fact that the Baghdad Railway had a significant contribution to the causes that led the Ottoman Empire to be engaged into the Great War. In addition, apart from the Ottoman mistakes that resulted in the disintegration of that empire, it was also the blow of the European imperialism that hit the country, namely turning it into an underdeveloped and vulnerable entity.

\subsection{A retrospective analysis; lessons learned and policy implications}

In the historical continuum, although the revolutionary movement of the sultanate finally supported the Baghdad Railway, the Neo-Turks primarily considered that the country had to get rid of external administrative assistance, foreign capital invested in long-term economic concessions as well as foreign policy intervention. During that transition period, which the country did not succeed to learn the secrets of the Western progress and adapt this acumen to its own needs. In other words, the only way to the survival of the Ottoman rulers would have been, as it was proved a few years later with Kemal Ataturk and his massive reforms, a government with progressive character to make use of the European capital and technical assistance in favor of the empire's welfare (Karkazis, Baltos, \& Vidakis, 2017).

In an analysis that had been written by Maloney (1959) and was republished in 1984 by the Naval Group of Study, Center of Naval Analysis, USA, the Baghdad Railway is described as a project of wide perception and scanning in the field of application. The growing interest of Germany, however, caused the reaction of Russia, France and England. The East German historian Rathmann (1962), using Marxist rhetoric, criticized the way that the railway issue had been handled, mostly as a nationalist policy, and noted the economic importance of the railway in a context of monopolistic capitalism. The Turkish historian, Keskin, (1978) repeated the conviction of Rathmann and approached the railway as an example of a premeditated dominance over the Ottomans, the "Trojan Horse" of the Great Powers. He also claimed that the discovery of resources along the track of the railway strengthened the competition among them.

Later in 2001, Jonathan S. McMurray denied the German character of the Railway, intending to provide a more detailed report of the Ottoman contribution. In McMeekin's study (2010), the roots of today's disasters in the Middle East are conventionally attributed to the post-war cynicism of the Entente Powers, although he poses the question why Germany's responsibility has not been recognized accordingly. McMeekin believes that William II convinced the Ottomans to take part in the First World War offering a mix of gold, plunders and promises. Hamid was dethroned by the NeoTurks in 1909, but the failure of the British to support the reformists is partly due to the continued ties between the Turks and Germany, after the fall of Hamid. Finally yet importantly, for Ozyuksel (2016), Professor of History and Political Sciences at the University of Istanbul, the expansion of the railways was the great industrial project of the late 19th century and the Great Powers gained increased commercial benefits. Using new Ottoman sources, Ozyuksel proves how Berlin-Baghdad railway became a symbol of both the rising European power and the declining Ottoman Empire. 


\section{Conclusion}

From the previous observations, it is concluded that the competition of the Great Powers co-existed with cooperative tactics and synergies, resulting in bipolar and multipolar forms of rivalry and conflict, where the interests of smaller countries, even allied ones, are usually subordinated in a process where economic control plays the major role (Campos \& Fernandes, 2017). Geo-energy, other words "geo-energeia", demonstrated a central role, as depicted at the Graph 1 below (Vidakis \& Baltos, 2015).

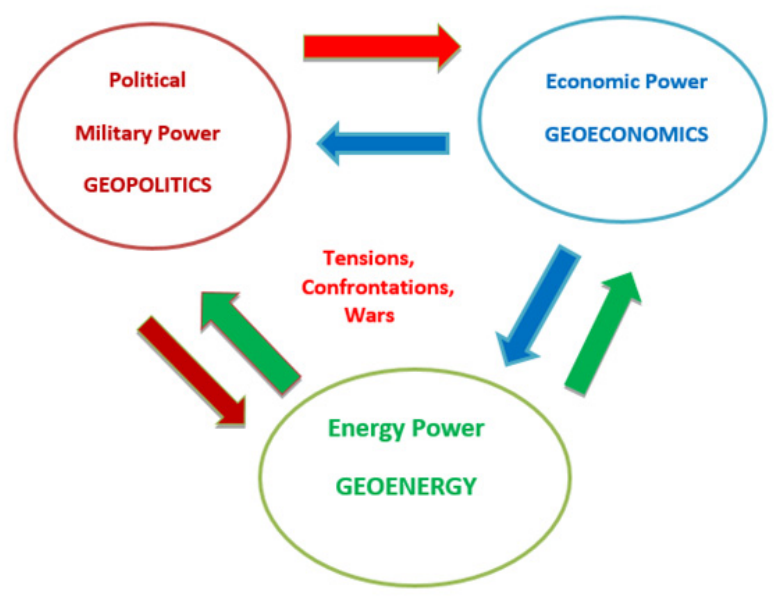

Figure 1. Pattern of Power forms interconnected - "The Supremacy Triangle" (Vidakis, Baltos \& Balodis, 2017)

Recalling the main points of Earle's rich and in-depth study, we may highlight that England's strategy after 1902 and even more than 1911, was no longer the strategy of equal sharing of profits and oil from the Ottoman Empire with an increasingly powerful Germany, but the highest share of the spoils, that would help England to maintain its dominant position in the World Powers distribution scheme.

As a result, it was unable to reconcile, as France did, with a short-term balanced distribution of the benefits, which was not realized by Kaiser and the Neo-Turks. On the other hand, the Ottoman Empire chose the railway in an attempt to substitute maritime transportations, but the significant lack of naval power condemned this effort since it was extremely vulnerable over its maritime borders. In addition, the final choice of the supposed optimal railway track proved to be inappropriate - it had a high cost in capital and time, resulting in the serious delay of the project. The revolution of the Neo-Turks, the Italian-Ottoman conflict and the Balkan wars contributed in the decisive delay of the construction of the line. The view of the Ottoman leadership that it would have been free to choose and develop own capabilities, while being vulnerable in many sectors and burdened with several drawbacks, was tragically wrong.

In addition, the German efforts to avoid the objections of the other Great Powers drastically failed, mainly due to a lack of understanding of other basic geopolitical goals, i.e. France and the liberation of Alsace-Lorraine, Russia and the occupation of the straits, Great Britain and the protection of India, or the growing importance of oil value for England at the beginning of the 20th century. (Vidakis \& Baltos, 2013). Subsequently, the Arab lands were divided, thus it could not be any unified Arab dominance and unity from the Persian Gulf to the Eastern Mediterranean (geoeconomic and geopolitical power as well as geo-energeia/geo-energy power factor from the beginning of the 20th century). The oil of the region and especially the need for a powerful secular Turkey as a containment for the Soviets redefined and reoriented the English geopolitics towards 
eventually supporting of Kemal (Baltos, Vidakis, \& Balodis, 2017). The revisions of specific aspects of the Eastern Question as well as the restoration of Earle's related analyses offer indeed a sound sense of long-term strategic interpretation of Middle-eastern past and present turmoil politics.

\section{References}

Alobeid, A., Vidakis, I., Baltos, G., \& Balodis, J. (2018). The International Energy Strategies Ruling the Middle East for a Century Re-appear and Determine the Destiny of the Whole Eastern Mediterranean Region. Mediterranean Journal of Social Sciences, 9(4), 241-249.

Athanassopoulos, A. D, \& Karkazis, J., (1997). The efficiency of social and economic image projection in spatial configurations. Journal of Regional Science, 37 (1), 75-97.

Atwood, V. H. (2013). The Baghdad Railway. M.A. The University of Texas at Austin.

Baltos, G., Vidakis, I., \& Balodis, J. (2017). Turkey's Ambitions to Emerge as a Regional Power: Example or Counter-Example for Potential Aspiring Competitors. Academic Journal of Interdisciplinary Studies, 6(3), 25-32.Benns, F. L. (1941). European history since 1870. 4th edition. New York, p. 78.

Bilgin, M. S. (2004). The construction of the bagdad railway and its impact on Anglo-Turkish relations, 19021913. Osmanlı Tarihi Araştırma ve Uygulama Merkezi Dergisi OTAM, 16(16), $109-129$.

Campos, A., \& Fernandes, C. P. (2017). The Geopolitics of Energy. Geopolitics of energy and energy security. Idn cadernos 23.

Dicey, E. (1866). The New Germany. Macmillan's magazine, 1859-1907, 14(84), 480-488.

Dicey, E. (1903). The Rival Empires. The Nineteenth century and after: a monthly review, 54(322), 885-902.

Earle, E. M. (1923). Turkey, the Great Powers, and the Baghdad Railway: a Study in Imperialism. New York, Macmillan, reprinted July 1924, New York: Press of J. J. Little \& Ives Company.

Fraser, D. (1909). Short cut to India: The record of a journey along the route of the Baghdad railway. (Classic Reprint), Forgotten Books 2016, William Blackwood and Sons, Edinburgh and London.

Fromkin, D. (1989). A Peace to End All Peace: The Fall of the Ottoman Empire and the Creation of the Modern Middle East. New York: Henry Holt and Co.

Geraud, A. (1914). A new German empire: the story of the Baghdad Railway. The Nineteenth Century, 958-972.

Gwinner, A. (1909). The Baghdad Railway and the Question of British Cooperation. The Nineteenth Century, 1083-1094.

Hertner, P. (2006). The Balkan Railways, International capital and Banking from the End of the 19th Century until the Outbreak of the First World War. Bulgarian National Bank.

Hogarth, D. G. (1915). Geography of the War Theatre in the Near East. The Geographical Journal, 45(6), 457467.

Hülagü, M. M. (2010). The Hejaz railway: the construction of a new hope. Blue Dome Press.

Illich, N. S. (2007). German imperialism in the Ottoman Empire: A comparative study. Texas A\&M University.

Jäckh, E. (1915). Die deutsch-türkische Waffenbrüderschaft. Deutsche Verlags-Anstalt.

Jones, G. (1981). The state and the emergence of the British oil industry. The Macmillan Press LTD.

Karkazis J., Vidakis I., \& Baltos G. (2014). The Syrian Energy Policies of the Four Seas and Their Geopolitical Repercussions, Sosyoekonomi, 22 (22), $105-116$.

Karkar, Y. N. (1972). Railway development in the Ottoman Empire, 1856-1914: Vantage Press.

Keskin, H. (1978). Die Turkei vom Osmanischen Reich zum Nationalstaat: Werdegang einer Unterentwicklung. Berlin: Olle \& Wolter.

Kumar, R. (1962). 2. The Records of the Government of India on the Berlin-Baghdad Railway Question. The Historical Journal, 5(1), 70-79.

Landau, J. M. (2016). The Hejaz Railway and the Muslim Pilgrimage: A Case of Ottoman Political Propaganda. Routledge.

Lynch, H. (1911). The Baghdad railway. Fortnightly, 89(531), 375-387. Maloney, A. P. (1959). The BerlinBaghdad Railway as a Cause of World War I. New York University, Naval Studies Group, (1984). Professional Paper 401, Center for Naval Analyses, Virginia.

McMeekin, S. (2010). The Berlin-Baghdad Express: The Ottoman Empire and Germany's Bid for World Power, 1898-1918. Penguin Books Ltd.

McMeekin, S. (2012). The Berlin-Baghdad Express. Harvard University Press.

McMurray, J. S. (2001). Distant ties: Germany, the Ottoman Empire, and the construction of the Baghdad railway. Greenwood Publishing Group.

Middleton, W. D. (2011). The Bosporus crossing: the Middle East from Berlin to Baghdad. Railroad History (204).

Ozyuksel, M. (2016). The Berlin-Baghdad Railway and the Ottoman Empire: Industrialization, Imperial Germany and the Middle East. I.B.Tauris. 
Pallini, C., \& Scaccabarozzi, A. (2011). " Technical landscape" in heart of a city: a project for the Sirkeci railway siding in Istanbul. Paper presented at the Conservation of Architecture, Urban Areas, Nature \& Landscape.

Papadiamantis, A. (2011). The Merchants of Nations. Sunstep Publishing.

Pears, E. (1908). The Baghdad Railway. Contemporary Review, 94, 570-591.

Rathmann, L. (1962). Berlin-Baghdad: Die Imperialistische Nahostpolitik des kaiserlichen Deutschlands. Berlin: Dietz-Verlag.

Rogan, E. L. (2015). The fall of the Ottomans: The Great War in the Middle East. Athens: Alexandria Publishing.

Rohrbach, P. (1915). Der Krieg und die deutsche Politik: Verlag" Das Grössere Deutschland". Kommission Beim Deutschen Kolonial-Verlag, Berlin.

Schreiner, G. A. (1918). From Berlin to Bagdad: behind the scenes in the Near East. Harper \& Brothers.

Somerwil-Ayrton, K. (2007). The Train that Disappeared Into History: The Berlin-to-Bagdad Railway and how it Led to the Great War. Uitgeverij Aspekt.

Stellakou, V., \& Karkazis, J. (1992). Evaluation of effects of infrastructure on the long-term viability of an investment, SPOUDAl, 42, 4-16.

Trumpener, U. (2015). Germany and the Ottoman Empire, 1914-1918 (Vol. 2206). Princeton University Press.

Vidakis I., Baltos G., \& Balodis, J. (2017). Geopolitics of Energy versus Geoenergy of Politics, Social sciences bulletin, 2 (25), 38-55.

Vidakis I., \& Baltos G. (2015) Security Aspects of Geoenergeia and the Significance of Energy Resources Management in International Politics. Geopolitics of Energy, 37 (3), Canadian Energy Research Institute.

Vidakis, I. G. (2016). Energy network's security in Eastern Mediterranean Sea. (Ph.D Disseration), University of the Aegean, Chios, Greece.

Wiedemann, M. (1911). Bagdad und Teheran: politische betrachtungen und berichte. Deutsche Orientkorrespondenz in kommission beim Deutschen kolonialverlag.

Woods, H. C. (1917). The Baghdad railway in the war. Fortnightly, 102(608), 235-246.

Yergin, D. (2009). The Prize: The Epic Quest for Oil, Money and Power. New York: Free Press. 